\title{
RESENHA
}

\section{The Post-American World*}

FÁBIO ALBERGARIA QUEIROZ**

Passadas quase duas décadas do fim da Guerra Fria e da rigidez bipolar, ainda hoje permanecem muitas incertezas acerca da natureza do atual sistema internacional. Assim, neste complexo cenário em que os destinos de seus atores se entrelaçam num contexto favorável a conexôes da mais variada ordem, surgem algumas questôes paradigmáticas. Qual o cenário que se desenha para o futuro próximo? E qual o papel a ser desempenhado pela superpotência remanescente nesta nova ordem? Estas indagações norteiam a reflexão que faz Fareed Zakaria em seu mais novo livro, The Post-American World, uma obra que se apresenta como uma lúcida leitura acerca do mundo pós-Guerra Fria e das tendências que lhe dão forma.

Apesar de o título, à primeira vista, nos remeter à assertiva "duroselliana" de que todo império perecerá (DUROSELLE, Jean-Baptiste. Todo Império Perecerá: Teoria das Relaçôes Internacionais. Editora UnB: Brasília, 2000), The Post-American World não é mais um prelúdio sobre o declínio da proeminência norte-americana no mundo. A obra é uma saudação ao nascimento de uma genuína ordem global marcada pela ascensão de outros atores dotados de significativos recursos de poder. Para chegar a este ponto, inicialmente Zakaria descreve as três grandes mudanças tectônicas que ocorreram ao longo dos últimos quinhentos anos e que moldaram o sistema internacional.

A primeira delas foi a ascensão do mundo ocidental iniciada no século XV e que, a partir de sua incrível expansão, ao fim do século XVIII, lançou as bases da modernidade tal qual conhecida atualmente. A ascensão dos EUA no século XIX como a maior potência mundial, a única na história capaz de rivalizar qualquer provável combinação entre Estados, marcou a segunda grande mudança na estrutura internacional de poder ao ensejar, principalmente ao longo dos últimos vinte anos, um domínio sem precedentes nos registros da História Moderna.

Por fim, vivenciamos hoje o cenário referendado na obra, a terceira grande mudança na estrutura de poder da era moderna denominada por Zakaria como

\footnotetext{
* Resenha de ZAKARIA, Fareed. The Post-American World. New York and London: W. W. Norton \& Company. 2008, 292 p. ISBN 978-0-393-06235-9.

** Doutorando em Relações Internacionais pela Universidade de Brasília - UnB (fabioaq@hotmail.com).
} 
"the rise of the rest". Esta emergente configuração é marcada por uma grande difusão de poder em que seus atores, muitos deles não-estatais, não são apenas meros coadjuvantes, mas sim atuantes players capazes de determinar os rumos da sociedade internacional em suas várias dimensões (p.36). E qual o papel dos EUA em tal estrutura?

Embora, para Zakaria, no nível político-militar, o mundo ainda seja unipolar, sob a hegemonia norte-americana, nas demais esferas - industrial, econômica, financeira, social, cultural - há uma significativa mudança na distribuição de poder em favor de outras potências, o que de forma alguma sugere um possível declínio do poderio dos EUA.

Isso porque o país se mantém na vanguarda dos avanços e inovações em áreas vitais como ciência e tecnologia, segundo Zakaria, os combustíveis que o movem e garantem sua proeminência. Portanto, o poderio militar dos EUA não é causa de sua força, mas sim a conseqüência.

Desta forma, neste cenário rotulado como "pós-americano", o reconhecimento por parte dos EUA da existência de uma ordem marcada pela ascensão de uma miríade de atores relevantes em termos de poder, bem como sua capacidade de conviver harmoniosamente como parte dela, são questôes fundamentais com as quais se depara o sistema internacional para garantir sua estabilidade.

Eis, então, o papel central a ser desempenhado pelos EUA. Nesta estrutura eles terão menor poder relativo, contudo, suas idéias e ideais continuarão dominantes. Assim, os EUA encontram, à sua frente, uma grande oportunidade de moldar e liderar este processo de mudança, mas somente se aceitarem que o "mundo pósamericano", composto por uma grande diversidade de vozes, é uma realidade a ser celebrada, e não contestada.

Caso contrário, adverte Zakaria, corre-se o risco de se vivenciar uma profunda dissuasão de poder causada pela emergência de incontroláveis forças contestatórias. Portanto, o desafio central neste cenário marcado pela "ascensão do resto" está em impedir que as forças do crescimento global se tornem as forças da desintegração da ordem mundial construída ao longo das últimas décadas.

Por fim, cumpre destacar alguns aspectos de caráter teórico particularmente relevantes para os internacionalistas que se debruçarem na leitura desta obra. Como perceptível, Zakaria utiliza a análise sistêmica em termos de subdivisóes setoriais e considera o comportamento dos agentes em termos de seus atributos, o que nos permite verificar a distribuição de capacidades entre os diferentes atores em cada um destes setores de forma independente.

Com base nesta abordagem, torna-se perfeitamente possível considerar que, em um dado campo, como o econômico, haja uma estrutura multipolar ao passo que, na esfera político-militar, por exemplo, prevaleça, ainda, a unipolaridade, o que aproxima o modelo de Zakaria ao sistema uni-multipolar de Samuel Huntington (HUNTINGTON, Samuel. The Lonely Superpower. Foreign Affairs, vol. 78, n.02, Mar/Apr.1999, p.35-49). 
Igualmente relevante é a importância conferida por Zakaria a elementos cognitivos na composição desta estrutura. $\mathrm{O}$ autor mantém a importância das forças materiais, contudo, ressaltando que o significado atribuído pelos atores a elas é, em muitos casos, determinante, o que o aproxima da perspectiva construtivista de Alexander Wendt (WENDT, Alexander. Social Theory of International Politics. Cambridge: Cambridge University Press, 1999) que propõe uma leitura sociológica das relações internacionais como uma ponte entre a epistemologia positivista (existência de uma realidade objetiva) e a ontologia pós-positivista (realidade socialmente construída).

Observa-se, então, que, no mundo pós-americano de Zakaria, as idéias e as imagens nacionais, ou identidades, atuam como elementos capazes de influenciar no estabelecimento de objetivos e na ordenação de preferências na formação dos interesses destes atores. Quando discorre sobre os super-emergentes - China e Índia-Zakaria utiliza argumentos que permitem ao leitor inferir que as idéias não dizem respeito apenas ao ambiente social no qual os atores interagem, mas também ao conteúdo de questôes materiais e ao significado de poder que é constituído por contextos culturais onde as identidades tomam forma.

Em suma, nesta agradável leitura construída em estilo leve e fluido, contudo sem superficialidades, Zakaria traz ao campo de estudo uma nova visão sobre a distribuição de poder nas relações internacionais do pós-Guerra Fria, o que faz da obra uma importante referência. No atual momento paradigmático em que os EUA demonstram a vitalidade de sua democracia ao eleger o primeiro presidente negro de sua história, após oito anos de um governo contestado e controverso, The Post-American World surge não apenas como um convite à reflexão, mas como leitura indispensável para se compreender a natureza das forças profundas que moldam a estrutura internacional.

Mesmo para aqueles que discordem do proposto continuísmo da proeminência norte-americana na conformação deste cenário, os insights apresentados nesta obra, de forma lúcida e coerente, nos apontam um novo caminho a ser trilhado tendo como baluarte o colosso norte-americano, mais vigoroso do que nunca, contudo, não mais sozinho na condução dos rumos desta nova e desafiante jornada.

Recebido em 15 de novembro de 2009 Aprovado em 15 de maio de 2009 